ISCKMC 2020

International Scientific Congress «KNOWLEDGE, MAN AND CIVILIZATION»

\title{
STUDY OF PERSONAL CAREER ORIENTATIONS AT THE FINAL STAGE OF HIGHER EDUCATION
}

\author{
Inobat Erina (a), Yana Zalevskaya (b)*, Irina Sultanova (c), Evgeniya Fanina (d), \\ Olga Melnik (e) \\ *Corresponding author
}

(a) Sevastopol state University, 33, Universitetskaya str., Sevastopol, Russia, irinagorbushina@mail.ru,

(b) V.I. Vernadsky Crimean Federal University, 2A, Sevastopolskaya Str., Yalta, Russia ya.zalevskaya18@gmail.com,

(c) Sevastopol state University", 33, Universitetskaya str., Sevastopol, Russia, IVSultanova@ sevsu.ru, (d) State Autonomous educational institution Moscow city pedagogical University, 4, 2nd Agricultural road, Moscow, Russia, info@mgpu.ru,

(e) Armavir state pedagogical University, 159, Rosa Luxemburg str., Armavir, Russia, olga.anel2713@ gmail.com

\begin{abstract}
The article examines the problem of the development of career orientations among graduates as a necessary condition for their professional self-fulfillment. The process of career orientation development is influenced by both external (family, peers, society, culture) and internal (interests, values, motivation) factors. The university's objective is not only to give necessary theoretical and practical knowledge to students, but also to influencing their personal and professional development, helping to fulfill themselves in the profession, indicating the paths of development after completing their studies. The career orientations of students formed in the learning process determine career goals and prospects, which is reflected in the success of professional development in general. The existence of a variety of career orientations in professional interactions makes it easier to get through negative events and act more diligently in a changing environment. The article also presents an analysis of an empirical study of the characteristics of career orientations among graduates of various specialties (economists, psychologists, primary school teachers, and designers). On the basis of the data obtained, a project was developed to form career orientations and increase the level of professional self-development of graduates - Me and my career. The project is aimed at enhancing the career orientations of graduates as well as at the development of a mature professional personality and strengthening motivation for personal and professional growth.
\end{abstract}




\section{Introduction}

After graduation, a graduate faces a number of issues related to further professional development, career building and employment. Unfortunately, getting you degree of higher education does not always provide a graduate with an opportunity for further employment.

Therefore, an educational organization faces the main task of preparing not only theoretically, but also practically a professional graduate. Higher education will help student determine the success of his or her professional career. Educational programs of higher education should be focused not only on obtaining specific knowledge by students, but also on the development of personal quality - focus on the career growth. The career growth enables the graduate to further realize his or her inner potential and abilities. The problem of the development of career attitudes was reflected in the works of foreign (D.T. Hallom, P. Lambing, D. McClelland, D. Super, D.G. Winter) and domestic (A.S. Guseva, A.A. Derkach, I.D. Ladanov, A. K. Markova, EG Moll) researchers.

Table 1. Leading career orientations of future specialists using the Career anchor methodology

\begin{tabular}{|c|c|c|c|c|c|}
\hline \multirow{3}{*}{ Career orientations } & \multicolumn{5}{|c|}{ Career orientations study among students, 2020} \\
\hline & 44.03 .01 & 44.03 .01 & 54.03 .01 & 37.03 .01 & 38.03 .01 \\
\hline & $\begin{array}{l}\text { Preschool } \\
\text { education }\end{array}$ & $\begin{array}{l}\text { Primary } \\
\text { education }\end{array}$ & Design & $\begin{array}{c}\text { Practical } \\
\text { psychology }\end{array}$ & Economics \\
\hline $\begin{array}{c}\text { Entrepreneurial } \\
\text { creativity }\end{array}$ & 20.0 & 26.6 & 46.6 & 66.6 & 80.0 \\
\hline Challenge & 26.6 & 20.0 & 6.7 & 13.3 & 73.3 \\
\hline $\begin{array}{l}\text { Organizational } \\
\text { competence }\end{array}$ & 33.4 & 40.0 & 26.6 & 26.6 & 73.3 \\
\hline $\begin{array}{l}\text { Professional } \\
\text { competence }\end{array}$ & 26.0 & 46.6 & 66.6 & 26.6 & 46.6 \\
\hline Service & 66.6 & 73.3 & 46.6 & 40.0 & 73.3 \\
\hline Residence stability & 53.3 & 60.0 & 26.6 & 60.0 & 40.0 \\
\hline Autonomy & 46.6 & 53.3 & 86.6 & 40.0 & 60.0 \\
\hline $\begin{array}{l}\text { Integration of } \\
\text { lifestyles }\end{array}$ & 73.3 & 66.6 & 80.0 & 80.0 & 53.3 \\
\hline Job stability & 66.6 & 66.6 & 73.3 & 46.6 & 73.3 \\
\hline
\end{tabular}

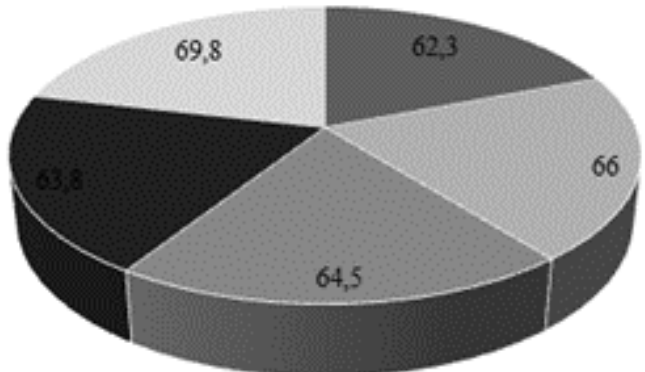

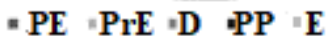

Figure 1. The results of average values of students from various fields of study obtained using Motivation for a Career method 


\section{Problem Statement}

The career development of university graduates is influenced by a number of factors, in particular, the presence of career orientations, development of adequate self-esteem, provision of self-fulfillment as a future employee (Teodorescu, 2018). The awareness of these factors at the beginning of building a career for young specialists will help choose the right path of personal development as a professional.

Modern requirements set for future specialists by the employers should make changes and additions to the process of preparing students with a focus on the development of their personal and professional development the manifestation of which can be observed in future career growth.

\section{Research Questions}

Conscious career planning is an important aspect for a person's professional development and selffulfillment. The choice of a career is made by an individual through his or her talents, professional development, motives, and values. The career orientation is a system of value orientations, social attitudes in relation to work, interests, socially conditioned motives for activity based on a person's past experience in the process of his or her socialization. The career orientations serve to manage, stabilize and integrate an individual's career. A person implements his or her career orientations not always consciously (Aron, 2016).

Career orientations could be the following:

- understanding of his or her place in the organizational hierarchical structure (Longson, 2004);

- focus of professional activity (Zabrodin, 2012);

- an attitude or system of attitudes regarding one's career (Aron, 2016);

- the technology based on which a specialist can carry out career planning (Cosmin \& IleanaLoredana, 2018).

There are eight main career orientations:

1. Professional competence. This orientation focuses on a person's abilities and talents in a specific area (scientific analysis, technical planning, financial evaluation, etc.). With this orientation, people strive for professionalism in their profession, but they quickly lose their passion for work, which does not provide an opportunity to develop their abilities and talents (Zabrodin, 2012).

2. Management. In this case the focus of an individual is aimed on effort unification of other people, complete responsibility for final results. The unification of various functions of the organization is of key importance. This job requires analytical skills, individual and group communication skills, and emotional restraint skills (Longson, 2004).

3. Autonomy (independence). In this orientation, the main thing for the personality is the detachment from the rules of organization, attitudes and boundaries. With such an orientation, a person tends to do everything in his or her own way, makes decision on the amount of work, does not obey the rules of organization, and can also refuse promotion and other resources to maintain his or her independence (Longson, 2004).

4. Stability. This career orientation is linked to the need for security and stability. In accordance with the orientation the person shifts the responsibility for career management to the employer. People 
with this orientation may be talented and occupy a high position in organizations, but, due to the need for a safe and stable job and life they often refuse to advance if there is a risk and temporary inconvenience, even if great opportunities open up before them (Pirogov, 2014).

5. Service. This orientation is aimed at working with people, helping people, serving humanity, making the world a better place, etc. With this orientation, a person will work in an organization that is consistent with his or her goals and values and will also help to realize the person's main values in life. Most often, these people work in the field of quality of products and goods, environmental protection, consumer protection, etc. (Zabrodin, 2012).

6. Challenge. In accordance with this career orientation a person strives to win over others, overcome obstacles, solve difficult problems, and so on. Such a person is determined to challenge. Fighting and winning is more important in this process than a specific field of activity or qualification (Longson, 2004).

7. Integration of lifestyles. A person with this orientation is aimed at combining different aspects of the lifestyle, striving to achieve balance in the family, career and self-development. Life in general is important for this person, i.e. where he lives, how he improves, than a specific job, career or organization (Zabrodin, 2012).

8. Entrepreneurship. With such a career orientation, a person seeks to create something new, to overcome obstacles. A person is ready to take risks. He prefers to work for himself, to have his or her own business, his or her own brand, financial wealth. For an entrepreneur, the main thing is to create a business, an organization that will be a continuation of himself (Pirogov, 2014).

Based on the available career orientations, the ideological ideas of students about the profession before entering the university are often not true. Studying at a university in the field of study they have, students may realize that the profession will not provide an opportunity to realize their abilities, capabilities and needs. There is a reassessment of career orientations that reflect the specifics of setting career goals and drawing up plans that determine the well-being of professional development in general (Asmolov \& Guseltseva, 2019). Therefore, it is very important that the ideas about the profession and their career orientations are objective and correspond to the chosen profession. Studentship is a professional basis, a time for active learning, gaining knowledge, and developing the foundation for further analytical development of a personality's value orientations (Voiko, 2012).

\section{Purpose of the Study}

To empirically investigate the characteristics of the career orientations of graduate students of various specialties. To develop a project for the development of career orientations and an increase in the level of professional self-development of graduate students - Me and My Career - on the basis of data obtained.

\section{Research Methods}

Based on a wide variety of existing practical tools for studying the characteristics of career orientations of graduate students (on the example of students of the Humanitarian Pedagogical Academy 
(branch) of Vernadsky Crimean Federal University in Yalta), the following psychodiagnostic methodologies were compiled:

1. The adapted methodology Career Orientation Inventory called the Anchors of a Career methodology. The methodology will make it possible to study the preferences of respondents for building a professional path and further career trajectory.

2. Questionnaire Motivation for a Career (methodology of A. Noe, R. Noe, D. Bachhuber, adaptation by E.A. Mogilevkin). With the help of this methodology graduate students can assess the degree of motivation to achieve success in the career growth.

3. Methodology the Scale of Self-Assessment of Professional Qualities (modification of the test by A.G. Shmelev). Students assess their personal qualities, which correspond to the concepts of professional potential "communication skills"; "activity", "self-control"; Eenergy; "intellectuality"; "competence".

The research involved 75 graduate students (4 courses) in the field study 37.03.01 Practical psychology (15 students), 44.03.01 Preschool education (15 students), 44.03.01 Primary education (15 students), 03/38/01 Economics (15 students), 03/54/01 Design (15 students). The study was conducted from 2019 to 2020 and was divided into three interrelated stages:

The first stage - theoretical and methodological - is aimed at searching and analyzing scientific and educational literature on the problem. The initial positions of the study were identified: the conceptual and methodological apparatus, the definition of the research base, the size of the research sample, the choice of diagnostic research methods were specified.

The second stage is experimental. Carrying out the diagnostic stage in the study. Processing of completed forms and respondent' answers. Differences inthe career orientations and the degree of career motivation were identified.

The third stage was devoted to the compilation of the content of the project for the development of career orientations of graduates - My Career and Myself - existing in the scientific field of practical psychology exercises, methods, training elements.

\section{Findings}

The respondents' preferences in building a professional path and a career trajectory were studied using the adapted methodology of A.A. Zhdanovich the Anchors of a Career (Table 1). The data obtained indicate that for the majority of future "Economists" the career anchors are clearly manifested in the scales of the "entrepreneurial creativity" of 12 people. $(80 \%)$, the scales of "organizational competence" and "challenge" - 11 people. (73.3\%), which indicates that today's graduates of this direction can be organizers not only of their own enterprise, but also take responsibility for performing various tasks from outside.

High indicators on the scale of "professional competence" were demonstrated by students from the program 54.03.01 Design - $66.6 \%$ (10 people). It can be assumed that the profession itself requires quality training. The results of their activities can be visualized and it will not work to hide the poor performance of their work.

To yield benefit for the country and people, to improve the world, etc. on the scale of service the following students are ready: 44.03.01 Preschool education (66.6 \%), 44.03.01 Primary education, 
38.03.01 Economics $73.3 \%$ (11 people). Students that are not ready for changes: 44.03 .01 Primary education and 37.03.01 Practical psychology $60.0 \%$ (9 people).

In building their careers, students from 03.04.01 Design $86.6 \%$ (13 people) and students from 38.03.01 Economics - $60.0 \%$ (9 people) - appreciate their freedom and independence. The indicators can be interpreted as follows, student designers are creative people and they are free in their practical activities. This is the most important indicator for them. As for the students of the economic field, given their high scores on the scale of "entrepreneurial creativity," there is an evidence of their high independence and independence in work.

The students of the program 54.03.01 Design and 37.03.01 Practical Psychology on the integration of style scale showed the same data of $80.0 \%$ (12 people). These students value life and strive to balance all of its areas. On the Stability of job the same data were also found among students of 54.03.01 Design, 38.03.01 Economics - 73.3 \% (11 people) and students from the programs 44.03.01 Preschool education, 44.03.01 Primary education - $66.6 \%$ (10 people). These respondents tend to work in one place, regardless of various factors.

The questionnaire Motivation for a Career (methodology of A. Noe, R. Noe, D. Bachhuber, adaptation by EA Mogilevkin). An analysis of the results obtained showed that there was no significant difference in the motivation for a career between the respondents. All groups of the respondents are motivated to advance their careers (Fig. 1). It should be noted that the graduates studying in the program 38.03.01 Economics (69.8 points) are very motivated for a career growth. These students are ready to plan a career, take into account the ongoing changes in the society, strive to be noted by the leaders for further advancement in the career ladder. The lowest average indicators were found among students of the program 44.03.01 Preschool education (62.3 points). Indicators denote low motivation among future teachers. These students do not show a great desire to work in the field of their study. They are already thinking that if they have to work in preschool educational organizations, it will be private preschool organizations or their own development center.

According to the indicators there follow students of the program 37.03.01 Practical Psychology (63.8 points). Similar to future teachers, it is difficult for them to see a career growth in their chosen profession. In the labor market today, these specialists are needed in organizations where wages are not high along with a high level of responsibility (an example is schools, kindergartens, summer camps, etc.)

The students of the program Design (64.5 points) and Primary education (66 points) scored almost the same points, which indicates their motivation and willingness to build a career, spend their potential and be active in the creative search for new knowledge.

According to the methodology the Scale of Self-Assessment of Professional Qualities (modification of the test by A.G. Shmelev), the respondents should assess their own level of development of professional qualities on a 7-point scale listed in the methodology. Particular attention during the analysis of answers was paid to the assessment of position No. 25 (Person focused on a career growth).

A high level of self-esteem of professional qualities was revealed in $20 \%$ (3 students) of future teachers, practical psychologists and future economists, $13.3 \%$ (2 students) of future primary school teachers and $40 \%$ (6 students) of future designers. The identified indicators show that they have a clear goal and an individual career path in achieving their goals. The majority of respondents presented an 
average level of self-assessment of professional qualities (40\% of educators, $46.6 \%$ of primary education teachers, $33.4 \%$ of designers, $60.0 \%$ of practical psychologists, $73.3 \%$ of economists). The professional purpose of these students is not well understood by them. There is an inadequate self-assessment of their actions and behavior, judgment towards career-oriented individuals. The remaining respondents $(40 \%$ of educators, $46.6 \%$ of primary education teachers, $26.6 \%$ of designers, $20.0 \%$ of practical psychologists, $6.7 \%$ of economists) have a low level of development of this component, which indicates the absence of a clear goal in achieving a career growth in the chosen profession. They tend to show a negative attitude towards students with expressed intentions to achieve a career growth.

Based on the experimental data obtained, we have designed a project for the development of career orientations and an increase in the level of professional self-development of graduate students - My Career and I. The aim of the project is to activate the career orientations of graduate students. The project also aims to:

- develop reflection of the professional 'myself';

- develop the professional self-concept in the structure of the personality of future specialists;

- develop readiness for independent, active cognitive activity in solving educational and professional tasks;

- develop skills for setting and achieving professional goals and auxiliary goals.

It is also designed to promote the development of a mature professional personality, enhance the motivation of personal and professional growth.

\section{Conclusion}

In the modern changes that are taking place in society, a professional consulting has been replaced by career consulting, in the mainstream of which a career is viewed as a continuous process of successful professional development and professional growth. The fulfillment of personal potential in a career is a process of conscious implementation of professional and job promotion. During the period of study students develop their career orientations on the basis of which the career goals and prospects are determined, which is reflected in the success of professional development in general.

Career orientations for most graduate students are focused on stability as a guiding career value. They prefer jobs that guarantee them safety and certainty. To a lesser extent, graduate students choose a career orientation challenge. Some students show equality in career orientations. In special cases, students do not choose a career orientation of professional competence at the end of their studies. The career orientation of students is influenced by thr following factors: awareness of career orientations of students; career tension; reflection indicator; features of career planning.

Based on the experimental data obtained, we have developed a priority project - Me career and myself - for the development of career orientations and an increase in the level of professional selfdevelopment of graduates. 


\section{References}

Aron, I. S. (2016). Social design as a technology for the formation of social and personal competencies of University students. VSTU.

Asmolov, A. G., \& Guseltseva, M. (2019). Education as a space of opportunities: from human capital to human potential. The European Proceedings of Social \& Behavioural Sciences, 64, 40-45.

Cosmin, M. I., \& Ileana-Loredana, V. (2018). Career development in students: motivation, personality factors, and vocational interests. The European Proceedings of Social \& Behavioural Sciences, 67 , 2049-2054.

Longson, S. (2004). Choose a career. Balance Busin. Books.

Pirogov, N. (2014). Life career. Palmarium Acad. Publ.

Teodorescu, A. -M. (2018). Education, the component of quality of life and human development. The European Proceedings of Social \& Behavioural Sciences, 67, 1880-1886.

Voiko, R. A. (2012). Professional formation of a student's personality in higher school. Russ. J. of Ed. and Psychol., 4, 40.

Zabrodin, Y. M. (2012). Psychology of personality and human resource management. Finstatinform. 